\title{
Deteriorative changes in maize kernels due to Aspergillus flavus Link. and Fusarium verticillioides (Sacc.) Nirenberg
}

\author{
Francis Collins MUGA ${ }^{1,2}$, Tilahun Seyoum WORKNEH ${ }^{1}$, Moses Okoth MARENYA ${ }^{3,4}$
}

Received February 04, 2019; accepted August 18, 2019.

Delo je prispelo 04. februarja 2019, sprejeto 18. avgusta 2019.

\begin{abstract}
Deteriorative changes in maize kernels due to Aspergillus flavus Link. and Fusarium verticillioides (Sacc.) Nirenberg

Abstract: The study aimed at measuring changes in chemical composition of maize kernels due to Aspergillus flavus Link. and Fusarium verticillioides (Sacc.) Nirenberg infection. The samples of maize kernels were incubated at $28^{\circ} \mathrm{C}$ for $7,14,21$, and 28 days. The samples were analysed for mycotoxin, moisture, crude fat, crude protein, crude ash, and crude fibre. Maize kernels inoculated with $A$. flavus and $F$. verticillioides exhibited a significant decrease in crude fat. Aflatoxin $\mathrm{B}_{1}\left(\mathrm{AFB}_{1}\right)$ contamination increased in maize kernels inoculated with $A$. flavus, and fumonisin $\mathrm{B}_{1}\left(\mathrm{FB}_{1}\right)$ in kernels inoculated with $F$. verticillioides. Crude ash and crude fibre content showed no changes. Incubation time significantly affected $\mathrm{AFB}_{1}$ and $\mathrm{FB}_{1}$ contamination levels, moisture, crude fat, and crude protein contents. $\mathrm{AFB}_{1}$ and $\mathrm{FB}_{1}$ contamination were significantly correlated with crude fat degradation. The tested strains had similar deteriorative effects on maize kernels. The significant changes in the proximate composition were only observed in maize kernels with mycotoxin contamination above the regulatory limit of $10 \mu \mathrm{g} \mathrm{kg}^{-1}$, thus not fit for human consumption.
\end{abstract}

Keywords: aflatoxin; fumonisin; maize kernel; mycotoxin; proximate components; fungal species
Kvarjenje koruznih zrn zaradi okužb z glivama Aspergillus flavus Link. in Fusarium verticillioides (Sacc.) Nirenberg

Izvleček: $\mathrm{V}$ raziskavi so bile merjenje spremembe $\mathrm{v}$ kemični sestavi koruznih zrn zaradi okužbe z glivama Aspergillus flavus in Fusarium verticillioides. Vzorci koruznih zrn so bili inkubirani pri temperature $28^{\circ} \mathrm{C}$ za $7,14,21$, in 28 dni. V vzorcih je bila analizirana vsebnost mikotoksinov, vode, celukopnih beljakovin, maščob, vlaknin in pepela. Koruzna zrna, okužena $\mathrm{z}$ glivama A. flavus in F. verticillioides, so imela značilen upad celokupnih maščob. Kontaminacija $\mathrm{z}$ aflatoksinom $\mathrm{B}_{1}\left(\mathrm{AFB}_{1}\right)$ se je v koruznih zrnih povečala po inokulaciji z glivo A. flavus, s fumonizinom $\mathrm{B}_{1}\left(\mathrm{FB}_{1}\right)$ pa po inokulaciji $\mathrm{z}$ glivo $F$. verticillioides. Pri vsebnostih celokupnega pepela in vlaknin ni bilo nobenih sprememb. Čas inkubacije je značilno vplival na vsebnost $\mathrm{AFB}_{1}$ in $\mathrm{FB}_{1}$, vsebnost vode, celokupnih maščob in beljakovin. Kontaminacija $\mathrm{z} \mathrm{AFB}_{1}$ in $\mathrm{FB}_{1}$ je bila značilno povezana $\mathrm{z}$ degradacijo celokupnih maščob. Testirani sevi so imeli podoben kvaren učinek na koruzna zrna. Značilne spremembe v zgradbi koruznih zrn so bile ugotovljene pri njihovi kontaminaciji z mikotoksini nad predpisano vrednostjo $10 \mu \mathrm{g} \mathrm{kg}^{-1}$, kar ni primerno za prehrano ljudi.

Ključne besede: aflatoksin; fumonizin; koruzna zrna; kemijska sestava; mikotoksin; vrste gliv

1 University of KwaZulu-Natal, School of Engineering, Department of Bioresources Engineering, South Africa

2 Corresponding author, e-mail: 215081106@stu.ukzn.ac.za / seyoum@ukzn.ac.za

3 University of Venda, School of Agriculture, Department of Agricultural and Rural Engineering, South Africa

4 Institute for Agricultural Engineering, Agricultural Research Council, South Africa. 


\section{INTRODUCTION}

Maize is highly susceptible to fungal infection. Consequently, the quality of the maize kernels deteriorates (Begum et al., 2013). Fungal development can cause a considerable modification in the chemical composition of stored grains (Kakde and Chavan, 2011). Fungal infection in grains is associated with losses in carbohydrates, proteins and lipids while moisture content and free fatty acid increase. Fungi produce hydrolytic enzymes including peroxidase, amylase, pectinases, proteases and lipases. These enzymes degrade biochemical components such as fats, protein, and carbohydrates leading to the loss of dry matter (Begum et al., 2013). Bhattacharya and Raha (2002) reported a decrease in carbohydrates and fat content in maize kernels and soya beans due to postharvest fungal infection. Jain (2008) reported a rapid increase in free fatty acids in damaged grains due to fungal infestation. Embaby and Abdel-Galil (2006) observed a reduction in carbohydrates, sugars and crude fat due to Fusarium in legume grains. Kakde and Chavan (2011) concluded that Aspergillus flavus was responsible for the maximum depletion of fat content and reducing sugars in safflower, soya bean and sesame.

Aspergillus flavus and Fusarium verticillioides are commonly occurring maize pathogens that can easily survive on dead plant materials as saprotrophs. They also cause aflatoxin and fumonisin contamination (Probst et al., 2014), especially in maize kernels that provide a good natural substrate for the fungi (Perrone et al., 2014). Nutrient composition is a key factor affecting mycotoxin production in maize kernels (Ma et al., 2015). Inherent materials in maize kernels such as starch, proteins and lipids represent significant carbon and nitrogen sources potentially available during seed infection by fungi (Mellon et al., 2002). Saccharides provide the primary carbon source for mycelial growth and mycotoxin production (Mellon et al., 2005). Fanelli and Fabbri (1989), Wilson et al. (2004), and Mellon et al. (2005) reported a relationship between lipid degradation and $\mathrm{AFB}_{1}$ production. Glucose, ribose, xylose, and glycerol are also good substrates for growth and aflatoxin production by A. flavus (Liu et al., 2016).

Maize serves as an important dietary staple in Sub Saharan Africa. Consequently, the nutritive value of maize is of importance. Maize is vulnerable to infection by toxigenic fungi (Abbas et al., 2006). The high temperature and high relative humidity experienced in most parts of Sub Saharan Africa, coupled with poor grain storage conditions predispose maize to toxigenic fungal attack (Oyekale et al., 2012). Consequently, it is necessary to investigate its nutritive integrity and the subsequent mycotoxin contamination during fungal infection.
The objective of this study was to evaluate the effect of A. flavus and F. verticillioides infection on the proximate composition of maize kernels.

\section{MATERIALS AND METHODS}

\subsection{INOCULUM PREPARATION}

Aspergillus flavus Link. (strain PPRI1314-UKZN) and F. verticillioides (Sacc.) Nirenberg (strain MRC826) were obtained from the Department of Plant Pathology, School of Agriculture, Earth and Environmental Sciences, University of KwaZulu-Natal, South Africa. The fungi were plated on potato dextrose agar (Merck, Darmstadt, Germany) at $25^{\circ} \mathrm{C}$ for five days, after which conidia were harvested by flooding a single culture with either Triton X-100 solution (A. flavus) or distilled water (F. verticillioides) and scraping the surface mycelia with a sterile scraper. The resulting suspensions were filtered through cheesecloth. The spore concentration was counted using a Neubauer hemocytometer, and diluted using distilled water to obtain a spore concentration of $4 \times 10^{6} \mathrm{cells} \mathrm{ml}^{-1}$ (Hruska et al., 2014).

\subsection{PREPARATION OF MAIZE SAMPLES}

The maize kernels were surface sterilised by immersing the kernels in a $5 \%(\mathrm{v} / \mathrm{v})$ sodium hypochlorite $(\mathrm{NaClO})$ solution and stirring for one minute. The maize kernels were thereafter rinsed twice with distilled water. The moisture content (MC) of the maize kernels was then adjusted to $205 \mathrm{~g} \mathrm{~kg}^{-1}$ dry matter (DM) by soaking samples in distilled water for 2 hours. The samples were thereafter put in sealed plastic bags and refrigerated at a temperature of $4{ }^{\circ} \mathrm{C}$ for 72 hours to ensure uniform moisture distribution.

\subsection{INOCULATION AND INCUBATION OF MAIZE}

Maize was retrieved from cold storage and allowed to equilibrate to room temperature. A total of 45 samples of maize kernels each of mass $3 \mathrm{~kg}$ was weighed into sterilised plastic bags. Five $\mathrm{ml}$ of spore suspension from $A$. flavus or F. verticillioides were sprinkled on the samples and mixed manually before being transferred to the incubator. Five $\mathrm{ml}$ of distilled water was sprinkled on control samples. All samples were incubated at a temperature of $28^{\circ} \mathrm{C}$ and sampling was done after $0,7,14,21$, and 28 days, respectively. The incubated samples were analysed 
for aflatoxin and fumonisin content, and proximate composition.

\subsection{ANALYSIS OF THE CHEMICAL COMPOSI- TION OF MAIZE KERNELS}

Aflatoxin and fumonisin analysis were done using a liquid chromatography-tandem mass spectroscopy (LCMS/MS) as outlined by de Kok et al. (2007). Two hundred and fifty grams of each sample was ground using a Retsch Rotor Mill (SK 1, Germany). Twenty five grams of the ground maize sample was mixed with $80 \mathrm{ml}$ of acetonitrile and $20 \mathrm{ml}$ of water and left to stand for 2 hours. The extract was filtered and diluted four-times with distilled water. Twenty $\mu$ l of the diluted extract was injected into the LC-MS/MS for analysis.

The liquid chromatography (LC) had an ultra-performance liquid chromatography, ethyle bridge hybrid column (Aquity, UPLC BEH C18 $1.7 \mu \mathrm{m} ; 2.1 \times 100 \mathrm{~mm}$ column). The mobile phase A and mobile phase B were $0.1 \%$ formic acid in water and $0.1 \%$ formic acid in ace-

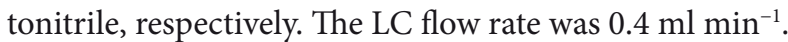
The eluent from the LC column was directed to the mass spectrometer. The electrospray source was operated in a positive ionisation multiple reaction monitoring (MRM) mode. The MRM transitions monitored for $\mathrm{AFB}_{1}$ were $313 \mathrm{~m} . \mathrm{z}^{-1}, 241 \mathrm{~m} \cdot \mathrm{z}^{-1}, 50 \mathrm{~V}$, and $47 \mathrm{~V}$ for parent ion, product ion, cone voltage, and collision voltage, respectively. The MRM transitions monitored for $\mathrm{FB}_{1}$ were $722 \mathrm{~m} \mathrm{z}^{-1}$, $334 \mathrm{~m} \mathrm{z}^{-1}, 50 \mathrm{~V}$, and $40 \mathrm{~V}$ for parent ion, product ion, cone voltage, and collision voltage, respectively. The data acquired were analysed using Waters Masslynx ${ }^{\mathrm{TM}}$ software. The limit of detection for the LC-MS/MS was $0.5 \mu \mathrm{g} \mathrm{kg}{ }^{-1}$, whereas the quantification limit was $2 \mu \mathrm{g} \mathrm{kg}^{-1}$.

The proximate components including MC, crude ash, crude fibre, crude fat, and crude protein, were anaysed using AOAC methods (AOAC, 2012).

\subsection{DATA PREPARATION AND STATISTICAL ANALYSIS}

A two-factor full-factorial design was used in this experiment, with the first factor at two levels and the second factor at five levels. The factors studied were fungal species (A. flavus, F. verticillioides) and incubation period $(0,7,14,21$, and 28 days $)$.

The data was subjected to analysis of variance (ANOVA) at $5 \%$ significance level to determine the effect of $A$. flavus and $F$. verticillioides on mycotoxin contamination (aflatoxin and fumonisin), crude fat, crude fibre, crude protein and $\mathrm{MC}$ of grains. Where a significant re- sult was obtained, the mean comparison was done using Duncan's Multiple Range Test. The correlation between mycotoxin contamination and proximate components was established using regression analysis. The analysis was done using GenStat ${ }^{\oplus} 17^{\text {th }}$ Edition (VSN International Ltd, Hemel Hempstead, United Kingdom).

\section{RESULTS}

The proximate composition and mycotoxin concentration at the start and during the experiment are presented in Table 1 . No $\mathrm{AFB}_{1}$ and Fumonisin $\mathrm{B}_{1}\left(\mathrm{FB}_{1}\right)$ was detected in the maize kernels prior to fungal infection. In this study, crude fat and crude protein content decrease with time while $\mathrm{AFB}_{1}, \mathrm{FB}_{1}$ and $\mathrm{MC}$ increased. The crude ash and crude fibre was unchanged with time.

The MC was significantly $(p<0.05)$ affected by incubation period and fungal species (Table 1). The MC increased with increasing time of incubation. The highest increase in MC was observed in samples inoculated with A. flavus (205 to $289 \mathrm{~g} \mathrm{~kg}^{-1}$, Table 1). The MC of samples inoculated with $F$. verticillioides ranged from 205 to 261 $\mathrm{g} \mathrm{kg}^{-1}$. The lowest increase in MC was observed in the control samples, ranging from 205 to $228 \mathrm{~g} \mathrm{~kg}^{-1}$.

There were no mycotoxins detected in the samples before incubation. Mycotoxin contamination was significantly $(p<0.05)$ affected by fungal species and the incubation duration. The levels of both $\mathrm{AFB}_{1}$ and $\mathrm{FB}_{1}$ increased with the incubation duration. The control samples showed no aflatoxin contamination at the end of day seven. However, $1 \mu \mathrm{g} \mathrm{kg}^{-1}$ of $\mathrm{AFB}_{1}$ was detected in the control samples on day 14 , increasing to $21 \mu \mathrm{g} \mathrm{kg}^{-1}$ and $141 \mu \mathrm{g} \mathrm{kg}^{-1}$ on day 21 and day 28 respectively. $\mathrm{FB}_{1}$ contamination was not detected in any of the control samples. The maize kernels inoculated with $A$. flavus resulted in $\mathrm{AFB}_{1}$ contamination ranging from $409 \mu \mathrm{g} \mathrm{kg}^{-1}$ on day 7 to $10,508 \mu \mathrm{g} \mathrm{kg}^{-1}$ on day 28 , while those inoculated with F. verticillioides resulted in $\mathrm{FB}_{1}$ contamination ranging from $212 \mu \mathrm{g} \mathrm{kg}^{-1}$ on day 7 to $2,447 \mu \mathrm{g} \mathrm{kg}^{-1}$ on day 28 (Table 1).

The crude fat content of maize kernels was $39 \pm$ $0.5 \mathrm{~g} \mathrm{~kg}^{-1}$ before incubation. The crude fat content decreased with increased fungal incubation time, while the fat content for the control samples was unchanged. Both the fungal species and the length of time of incubation significantly affected the crude fat content $(p<0.05)$. The greatest reduction in crude fat content was observed in the samples inoculated with $A$. flavus. The crude fat content ranged from $39 \mathrm{~g} \mathrm{~kg}^{-1}$ on day zero to $19 \mathrm{~g} \mathrm{~kg}^{-1}$ on day 28. The crude fat content for samples inoculated with $F$. verticillioides ranged from 39 to $31 \mathrm{~g} \mathrm{~kg}^{-1}$, whereas that of the control samples ranged from 39 to $37 \mathrm{~g} \mathrm{~kg}^{-1}$ (Table 
Table 1: Variation of chemical composition of maize with A. flavus and F. verticillioides and incubated for 7, 14, 21, and 28 days (dry matter basis)

\begin{tabular}{|c|c|c|c|c|c|c|c|}
\hline Taxon & Time (day) & $\begin{array}{l}\mathrm{MC} \\
\left(\mathrm{g} \mathrm{kg}^{-1}\right)\end{array}$ & $\begin{array}{l}\text { Mycotoxin } \\
\left(\mu \mathrm{gg}^{-1}\right)\end{array}$ & $\begin{array}{l}\text { Crude ash } \\
\left(\mathrm{g} \mathrm{kg}^{-1}\right)\end{array}$ & $\begin{array}{l}\text { Crude fat } \\
\left(\mathrm{g} \mathrm{kg}^{-1}\right)\end{array}$ & $\begin{array}{l}\text { Crude fibre } \\
\left(\mathrm{g} \mathrm{kg}^{-1}\right)\end{array}$ & $\begin{array}{l}\text { Crude protein } \\
\left(\mathrm{g} \mathrm{kg}^{-1}\right)\end{array}$ \\
\hline Control & 0 & $205^{g}$ & $0^{\mathrm{a}}$ & $11.8^{\mathrm{ab}}$ & $39.7^{\mathrm{g}}$ & $45^{\mathrm{a}}$ & $79.4^{\mathrm{f}}$ \\
\hline Control & 7 & $209^{\mathrm{fg}}$ & $0^{\mathrm{a}}$ & $11^{\mathrm{a}}$ & $39^{g}$ & $44^{\mathrm{a}}$ & $79^{\mathrm{f}}$ \\
\hline Control & 14 & $213^{\mathrm{fg}}$ & $1^{\mathrm{b}}$ & $11^{\mathrm{a}}$ & $39^{g}$ & $44^{\mathrm{a}}$ & $79^{f}$ \\
\hline Control & 21 & $218^{\mathrm{e}}$ & $21^{\mathrm{b}}$ & $11^{\mathrm{a}}$ & $38^{\mathrm{fg}}$ & $45^{\mathrm{a}}$ & $78^{\mathrm{f}}$ \\
\hline Control & 28 & $228^{\mathrm{e}}$ & $141^{\mathrm{b}}$ & $11^{\mathrm{a}}$ & $37^{\mathrm{ef}}$ & $45^{\mathrm{a}}$ & $76^{\mathrm{df}}$ \\
\hline A. flavus & 0 & $205^{\mathrm{g}}$ & $0^{\mathrm{a}}$ & $11^{\mathrm{a}}$ & $39^{g}$ & $45^{\mathrm{a}}$ & $79^{\mathrm{f}}$ \\
\hline A. flavus & 7 & $227^{\mathrm{e}}$ & $409^{\mathrm{b}}$ & $12^{\mathrm{a}}$ & $36^{\mathrm{e}}$ & $45^{\mathrm{a}}$ & $75^{\mathrm{cd}}$ \\
\hline A. flavus & 14 & $243^{\mathrm{d}}$ & $1,259^{b}$ & $12^{\mathrm{a}}$ & $33^{\mathrm{cd}}$ & $45^{\mathrm{a}}$ & $74^{\mathrm{bc}}$ \\
\hline A. flavus & 21 & $274^{\mathrm{b}}$ & $3,032^{\mathrm{b}}$ & $12^{\mathrm{a}}$ & $31^{\mathrm{b}}$ & $44^{\mathrm{a}}$ & $73^{\mathrm{b}}$ \\
\hline A. flavus & 28 & $289^{a}$ & $10,508^{\mathrm{b}}$ & $11^{\mathrm{a}}$ & $19^{\mathrm{a}}$ & $45^{\mathrm{a}}$ & $71^{\mathrm{a}}$ \\
\hline F. verticillioides & 0 & $205^{\mathrm{g}}$ & $0^{a}$ & $11^{\mathrm{a}}$ & $39^{\circ}$ & $45^{\mathrm{a}}$ & $79^{f}$ \\
\hline F. verticillioides & 7 & $217^{\mathrm{f}}$ & $212^{\mathrm{b}}$ & $11^{\mathrm{a}}$ & $36^{\mathrm{e}}$ & $45^{\mathrm{a}}$ & $77^{\mathrm{e}}$ \\
\hline F. verticillioides & 14 & $225^{\mathrm{ef}}$ & $604^{\mathrm{b}}$ & $12^{\mathrm{a}}$ & $35^{\mathrm{d}}$ & $45^{\mathrm{a}}$ & $75^{c}$ \\
\hline F. verticillioides & 21 & $253^{\mathrm{cd}}$ & $1,240^{\mathrm{b}}$ & $11^{\mathrm{a}}$ & $33^{c}$ & $45^{\mathrm{a}}$ & $74^{\mathrm{bc}}$ \\
\hline F. verticillioides & 28 & $261^{\mathrm{c}}$ & $2,447^{\mathrm{b}}$ & $11^{\mathrm{a}}$ & $31^{\mathrm{b}}$ & $45^{\mathrm{a}}$ & $73^{\mathrm{b}}$ \\
\hline \multicolumn{8}{|l|}{ Significance Level } \\
\hline Fungal taxon & $<.001$ & $<.001$ & 0.082 & $<.001$ & 0.677 & $<.001$ & \\
\hline Time & $<.001$ & $<.001$ & 0.349 & $<.001$ & 0.991 & $<.001$ & \\
\hline Fungal taxon $\times$ Time & $<.001$ & $<.001$ & 0.061 & $<.001$ & 0.241 & $<.001$ & \\
\hline $\mathrm{CV}$ & 0.013 & 0.433 & 0.001 & 0.017 & 0.002 & 0.004 & \\
\hline SE & 0.041 & 994.27 & 0.009 & 0.048 & 0.014 & 0.036 & \\
\hline $\operatorname{LSD}_{(p \leq 0.05)}$ & 0.123 & $2,880.3$ & 0.026 & 0.139 & 0.04 & 0.104 & \\
\hline
\end{tabular}

Means within a column followed by the same letter(s) are not significantly different according to Duncan's multiple range test $(p<0.05)$. nd $=$ not detected

1). The mean crude fat content of maize kernels inoculated with $A$. flavus and $F$. verticillioides were significantly $(p<0.05)$ different across all treatments.

The crude protein content decreased with incubation time. Both fungal species and the length of time of incubation significantly affected $(p<0.05)$ crude protein content of samples across treatments. The crude protein content of the maize kernels inoculated with A. flavus decreased from 79 to $71 \mathrm{~g} \mathrm{~kg}^{-1}$ over the 28 days of incubation. A reduction in the crude protein content from 79 to $73 \mathrm{~g} \mathrm{~kg}^{-1}$ was observed in the samples inoculated with $F$. verticillioides. The crude protein content of the control samples was fairly stable, ranging from 79 to $76 \mathrm{~g} \mathrm{~kg}^{-1}$.

The crude fibre content of the samples was relatively stable across all treatments. The fungal species and the incubation time had no significant effect $(p>0.05)$ on the crude fibre content of the maize kernels. The crude fibre content of the samples ranged from 45 to $44 \mathrm{~g} \mathrm{~kg}^{-1}$ (Table 1). Similarly, there was no significant difference in the crude ash content of the maize kernel samples across all treatments. Both the fungal species and the incubation time had no significant effect $(p>0.05)$ on the crude ash content of maize kernels. The crude ash content of the maize kernels ranged between 11 and $12 \mathrm{~g} \mathrm{~kg}^{-1}$ (Table 1).

The relationship between mycotoxin contamination and both crude fat and crude protein was best described by second order polynomial equations shown in Table 2 . A high coefficient of determination $\left(\mathrm{R}^{2}\right)$ was observed

Table 2: Regression equations for crude fat and crude protein of maize kernels contaminated with $\mathrm{AFB}_{1}$ and $\mathrm{FB}$

\begin{tabular}{lll}
\hline Mycotoxin & Equation & $\mathrm{R}^{2}$ \\
\hline $\mathrm{AFB}_{1}$ vs Crude fat & $1 \times 10^{-7} \mathrm{x}^{2}-0.003 \mathrm{x}+38.57$ & 0.986 \\
$\mathrm{FB}_{1}$ vs Crude fat & $1 \times 10^{-6} \mathrm{x}^{2}-0.0061 \mathrm{x}+38.74$ & 0.963 \\
$\mathrm{AFB}_{1}$ vs Crude protein & $1 \times 10^{-7} \mathrm{x}^{2}-0.002 \mathrm{x}+77.45$ & 0.821 \\
$\mathrm{FB}_{1}$ vs Crude protein & $1 \times 10^{-6} \mathrm{x}^{2}-0.0065 \mathrm{x}+78.84$ & 0.944 \\
\hline
\end{tabular}


between mycotoxin contamination and crude fat content $\left(\mathrm{R}^{2}=0.986\right.$ for $\mathrm{AFB}_{1}$ and $\mathrm{R}^{2}=0.963$ for $\left.\mathrm{FB}_{1}\right)$. The coefficient of determination between crude protein content and both $\mathrm{AFB}_{1}$ and $\mathrm{FB}_{1}$ was 0.821 and 0.944 respectively. No correlation was observed between mycotoxin contamination and either crude ash or crude fibre content.

\section{DISCUSSION}

The MC of the maize kernels increased with incubation time. A similar observation was made by Islam (2016) on stored black gram (Vigna mungo (L.) Hepper). The increase in moisture content with incubation time is attributed to respiration by maize kernels and fungi (Magan et al., 2004). The mycelial growth increased with time as evidenced by the progressive increase in $\mathrm{AFB}_{1}$ and $\mathrm{FB}_{1}$. The increased mycelial biomass escalated the respiration of fungi, hence, high $\mathrm{MC}$ on day 28 compared to the minimal change in $\mathrm{MC}$ at the start of the experiment. The increase in MC was higher for maize kernels inoculated with $A$. flavus compared to $F$. verticillioides. The incubation temperature of $28^{\circ} \mathrm{C}$ was optimal for the growth of A. flavus (Pratiwi et al., 2015) but unfavourable for $F$. verticillioides whose optimum temperature is around $25^{\circ} \mathrm{C}$ (Garcia et al., 2012).

The $\mathrm{AFB}_{1}$ and $\mathrm{FB}_{1}$ contamination of maize kernels increased over time because of the increasing mycelial biomass. There was a high $\mathrm{AFB}_{1}$ contamination as compared to $\mathrm{FB}_{1}$ contamination. Aspergillus flavus grows faster than $F$. verticillioides at the incubation temperature of $28{ }^{\circ} \mathrm{C}$ (Garcia et al., 2012; Pratiwi et al., 2015). Aflatoxin $\mathrm{B}_{1}$ contamination observed in the control samples could have been caused by internal infection (Mellon et al., 2007).

The greatest depletion of crude fats occurred in maize kernels inoculated with A. flavus. This observation is consistent with the findings by Kakde and Chavan (2011) who reported that $A$. flavus was responsible for the maximum depletion of fat content in cereals and oilseeds. Embaby and Abdel-Galil (2006) also observed a reduction in crude fat content in legume seeds due to Fusarium sp. Aspergillus flavus and F. verticillioides produce lipases that hydrolyse fats into fatty acids, which are subsequently degraded to provide a carbon and energy source (Kinderlerer, 1993).

The decrease in crude protein content observed in this study agrees with the findings of Reed et al. (2007) who associated changes in the protein content of maize with fungal degradation. The depletion of protein is attributed to its utilisation during the growth and metabolism of fungi (Bhattacharya and Raha, 2002). Liu et al. (2016) reported that amino acids such as glutamate, as- partate and arginine significantly promote $A F B_{1}$ production by $A$. flavus indicating protein utilisation. Results from this study are in tandem with previous research findings (Bhattacharya and Raha, 2002; Rheeder et al., 2009; Liu et al., 2016) that associated protein depletion with fungal deterioration.

Hydrolytic enzymes produced by $A$. flavus and $F$. verticillioides break down fats and proteins for use in fungal growth and development, which in turn creates conducive conditions for the production of mycotoxins (Liu et al., 2016). Fats are preferred over proteins as carbon substrates, hence, the high correlation between fats and mycotoxin contamination (Mellon et al., 2007).

\section{CONCLUSION}

Aspergillus flavus and F. verticillioides caused significant $(p<0.05)$ changes in the levels of crude fat and crude protein content of maize kernels. Although aflatoxin contamination was highly correlated with the depletion of crude fats, such changes can also be caused by $F$. verticillioides, which produces $\mathrm{FB}_{1}$. The proximate composition of maize samples with allowable mycotoxin contamination $\left(<10 \mu \mathrm{g} \mathrm{kg}^{-1}\right)$ was similar to uncontaminated maize kernels. Significant changes in proximate components were observed at mycotoxin contamination levels higher than the regulatory limit of $10 \mu \mathrm{g} \mathrm{kg}-1$, thus not fit for human consumption.

\section{ACKNOWLEDGEMENT}

This research was financially supported by the Department of Science and Technology (DST), Republic of South Africa through the University of Venda.

\section{REFERENCES}

Abbas, H. K., Cartwright, R. D., Xie, W., \& Shier, W. T. (2006). Aflatoxin and fumonisin contamination of corn (maize, Zea mays) hybrids in Arkansas. Crop Protection, 25(1), 1-9. https://doi.org/10.1016/j.cropro.2005.02.009

AOAC. (2012). Official Methods of Analysis of AOAC International. Gaithersburg, USA: AOAC International.

Begum, M. A. J., Venudevan, B., \& Jayanthi, M. (2013). Storage fungi in groundnut and the associate seed quality deterioration-A Review. Plant Pathology Journal, 12(3), 127-134. https://doi.org/10.3923/ppj.2013.127.134

Bhattacharya, K., \& Raha, S. (2002). Deteriorative changes of maize, groundnut and soybean seeds by fungi in storage. Mycopathologia, 155(3), 135-141. https://doi. org/10.1023/A:1020475411125

de Kok, A., Spanjer, M., Scholten, J., Rensen, P., \& Kearney, G. (2007). Rapid multi-mycotoxin analysis using AC- 
QUITY UPLC and Quattro Premier XE. Retrieved from http://www.waters.com/waters/library.htm?locale=en_ ZA\&lid $=1512802 \&$ cid $=511436$.

Embaby, E., \& Abdel-Galil, M. (2006). Seed borne fungi and mycotoxins associated with some legume seeds in Egypt. Journal of Applied Sciences Research, 2(11), 1064-1071.

Fanelli, C., \& Fabbri, A. (1989). Relationship between lipids and aflatoxin biosynthesis. Mycopathologia, 107(2-3), 115-120. https://doi.org/10.1007/BF00707547

Garcia, D., Barros, G., Chulze, S., Ramos, A. J., Sanchis, V., \& Marín, S. (2012). Impact of cycling temperatures on Fusarium verticillioides and Fusarium graminearum growth and mycotoxins production in soybean. Journal of the Science of Food and Agriculture, 92(15), 2952-2959. https://doi. org/10.1002/jsfa.5707

Hruska, Z., Rajasekaran, K., Yao, H., Kinkaid, R., Darlington, D., Brown, R. L., Bhatnagar, D., \& Cleveland, T. E. (2014). Coinoculation of aflatoxigenic and non-aflatoxigenic strains of Aspergillus flavus to study fungal invasion, colonization, and competition in maize kernels. Frontiers in Microbiology, 5(3), 122. https://doi.org/10.3389/fmicb.2014.00122

Islam, M. (2016). Effect of biotic and abiotic factors on quality of black gram seed. Ph.D. thesis, Sher-e-Bangla Agricultural University, Bangladesh.

Jain, P. (2008). Microbial degradation of grains, oil seeds, textiles, wood, corrosion of metals and bioleaching of mineral ores. Retrieved from http://nsdl.niscair.res.in/jspui/bitstream/123456789/558/1/MicrobialDegradation.pdf

Kakde, R. B., \& Chavan, A. M. (2011). Deteriorative changes in oilseeds due to storage fungi and efficacy of botanicals. Current Botany, 2(1), 17-22.

Kinderlerer, J. L. (1993). Fungal strategies for detoxification of medium chain fatty acids. International Biodeterioration \& Biodegradation, 32(1-3), 213-224. https://doi. org/10.1016/0964-8305(93)90053-5

Liu, J., Sun, L., Zhang, N., Zhang, J., Guo, J., Li, C., Rajput, S. A., \& Qi, D. (2016). Effects of nutrients in substrates of different grains on aflatoxin B1 production by Aspergillus flavus. BioMed Research International, 2016(2016), 1-10. https:// doi.org/10.1155/2016/7232858

Ma, H., Zhang, N., Sun, L. \& Qi, D. (2015). Effects of different substrates and oils on aflatoxin B1 production by Aspergillus parasiticus. European Food Research and Technology, 240(3), 627-634. https://doi.org/10.1007/s00217-0142364-Z

Magan, N., David, A., \& Sanchis, V. (2004). The role of spoilage fungi in seed deterioration. In D. Aurora (Eds.), Fungal Biotechnology in Agricultural, Food and Environmental Application (pp. 311-333) New York, NY: Marcel Dekker. https:// doi.org/10.1201/9780203913369.ch28
Mellon, J. E., Cotty, P.J., \& Dowd, M. K. (2007). Aspergillus flavus hydrolases: their roles in pathogenesis and substrate utilization. Applied Microbiology and Biotechnology, 77(3), 497-504. https://doi.org/10.1007/s00253-007-1201-8

Mellon, J. E., Dowd, M. K., \& Cotty, P. J. (2002). Time course study of substrate utilization by Aspergillus flavus in medium simulating corn (Zea mays) kernels. Journal of Agricultural and Food Chemistry, 50(3), 648-652. https://doi. org/10.1021/jf011048e

Mellon, J. E., Dowd, M. K., \& Cotty, P. J. (2005). Substrate utilization by Aspergillus flavus in inoculated whole corn kernels and isolated tissues. Journal of Agricultural and Food Chemistry, 53(6), 2351-2357. https://doi.org/10.1021/ jf040276g

Oyekale, K., Daniel, I., Ajala, M., \& Sanni, L. (2012). Potential longevity of maize seeds under storage in humid tropical seed stores. Nature and Science, 10(8), 114-124.

Perrone, G., Haidukowski, M., Stea, G., Epifani, F., Bandyopadhyay, R., Leslie, J. F., \& Logrieco, A. (2014). Population structure and Aflatoxin production by Aspergillus Sect. Flavi from maize in Nigeria and Ghana. Food Microbiology, 41(1), 52-59. https://doi.org/10.1016/j.fm.2013.12.005

Pratiwi, C., Rahayu, W. P., Lioe, H. N., Herawati, D., Broto, W., \& Ambarwati, S. (2015). The effect of temperature and relative humidity for Aspergillus flavus BIO 2237 growth and aflatoxin production on soybeans. International Food Research Journal, 22(1), 82.

Probst, C., Bandyopadhyay, R., \& Cotty, P. (2014). Diversity of aflatoxin-producing fungi and their impact on food safety in sub-Saharan Africa. International Journal of Food Microbiology, 174(1), 113-122. https://doi.org/10.1016/j.ijfoodmicro.2013.12.010

Reed, C., Doyungan, S., Ioerger, B., \& Getchell, A. (2007). Response of storage molds to different initial moisture contents of maize (corn) stored at $25 \mathrm{C}$, and effect on respiration rate and nutrient composition. Journal of Stored Products Research, 43(4), 443-458. https://doi.org/10.1016/j. jspr.2006.12.006

Rheeder, J., Shephard, G., Vismer, H., \& Gelderblom, W. (2009). Guidelines on mycotoxin control in South African foodstuffs: from the application of the hazard analysis and critical control point (HACCP) system to new national mycotoxin regulations (Medical Research Council Policy Brief). Retrieved from http://www.mrc.ac/policybriefs/mycotoxinguidelines.

Wilson, R. A., Calvo, A. M., Chang, P. K., \& Keller, N. P. (2004). Characterization of the Aspergillus parasiticus $\Delta 12$ desaturase gene: a role for lipid metabolism in the Aspergillus-seed interaction. Microbiology, 150(9), 2881-2888. https://doi.org/10.1099/mic.0.27207-0 